\title{
Progress in Administrative Decentralisation in Transformation Countries - a Comparative Survey*
}

\author{
Peter Jordan
}

\begin{abstract}
Decentralisation has an important meaning in the context of European integration, since a Europe composed of subsidiary spatial units is to be constructed and a "Europe of regions" is on the agenda of many political discussions. From the early 1990s, the European Communities (EC), later the European Union (EU), promoted the idea of administrative decentralisation also in transformation countries. For EU accession, decentralisation was made one of the prerequisites. But it met centralistic traditions originating not only in the Communist era and could be partly enforced only with considerable difficulties.
\end{abstract}

The paper investigates in a comparative way the efforts made and the results achieved so far in East-Central and Southeast European countries to establish local as well as regional self-government. A special focus is laid on the regional level, to which administrative powers have been devolved only later and partly insufficiently. Special attention is also paid to the correspondence of administrative regionalisation with historical regional and cultural identities.

Key words: administrative decentralisation, regional identities, European integration, political geography

\section{Napredak u administrativnoj decentralizaciji zemalja u tranziciji - komparativna analiza}

Decentralizacija ima važno značenje u kontekstu europskih integracija, s obzirom na nastojanje stvaranja ujedinjene Europe sastavljene od pomoćnih prostornih jedinica, a i ,Europa regija” tema je mnogih političkih diskusija. Od ranih 1990-ih Europska zajednica, kasnije Europska unija, promiče ideju administrativne decentralizacije i u zemljama u tranziciji. Decentralizacija je i jedan od uvjeta pristupa Europskoj uniji, ali tom procesu suprotstavila se tradicija centralističkog uređenja koja svoje korijene dijelom vuče iz razdoblja komunističkog upravljanja i on se mogao sprovesti djelomično i uz poteškoće.

U ovom članku uspoređuju se napori i do sad postignuti rezultati u zemljama istočne i jugoistočne Europe u formiranju lokalne i regionalne samouprave. Poseban naglasak stavljen je na regionalnu razinu na koju se prijenos centralne vlasti odvio kasnije i samo u manjoj mjeri. Također, naglasak je stavljen na analizu preklapanja administrativnih regija s povijesnim regionalnim i kulturnim identitetima.

Ključne riječi: administrativna decentralizacija, regionalni identiteti, europske integracije, politička geografija 


\section{INTRODUCTION}

Administrative decentralisation in the sense of a transfer of administrative competencies from superordinate to subordinate territorial-administrative units has an important meaning in the context of European integration, since a Europe composed of subsidiary spatial units is to be constructed and a "Europe of regions" is on the agenda of many political discussions. From the early 1990s, the European Communities (EC), later the European Union (EU), promoted the idea of administrative decentralisation also in transformation countries. For EU accession, decentralisation was made one of the prerequisites. But it met centralistic traditions originating not only in the Communist era and could partly be enforced only with considerable difficulties.

The paper investigates in a comparative way the efforts made and the results achieved so far in East-Central and Southeast European countries to establish local as well as regional self-government. ${ }^{1}$ A special focus is laid on the regional level, to which administrative powers have been devolved only later and partly insufficiently. Special attention is also paid to the correspondence of administrative regionalisation with historical regional and cultural identities (cf. a.o. to Paasi 1995).

The two examples (Croatia, Poland) are just to illustrate the way how every single country was regarded. The comparative view, especially the final synopsis as represented by Fig. 1 - not the presentation of new findings on an individual country like, e.g., Croatia - is the potential merit of this paper. Croatia has been taken as an example, since this article is to be published in Croatia. There is no claim that this article presents anything new or so far unknown on the Croatian administrative system.

\section{GENERAL CHARACTERISTICS, CAUSES AND OBJECTIVES OF THE DECENTRALISATION PROCESS IN THE TRANSFORMATION COUNTRIES OF EASTERN EUROPE}

In the course of the transformation process, the countries of Central and Southeast Europe increasingly came under the influence of the European Communities, which had become the European Union in 1994. They accepted this and were themselves (with some initial, but in the end only a few exceptions) very eager regarding integration. Amongst other things, this meant the consideration of the principle of subsidiarity ${ }^{2}$ as it is represented by the EU (Preamble and Article 2 of the Maastricht Treaty).

However, in contrast particularly to West-Central Europe (Switzerland, Germany, Austria), there is little tradition of subsidiarity in the transformation countries of Eastern Europe. This applies especially to East and Southeast Europe, to a lesser extent to EastCentral Europe, where the countries belonging to the Austrian part of the Austrian-Hungarian Monarchy as well as Transylvania [Ardeal], Croatia, but also Poland and Hungary, feature certain federalist traditions.

The centralistic administrative principle that was used early on by the Roman and Eastern Roman Empire was faithfully continued by Byzantium and carried into all parts of Byzantine-dominated East and Southeast Europe. The Ottoman Empire also adopted 


\begin{tabular}{|c|c|c|c|c|c|c|c|c|c|c|c|c|c|c|c|c|c|}
\hline 1989 & PL & $\mathrm{CZ}$ & SK & $\mathrm{HU}$ & SI & HR & $\mathrm{BA}$ & ME & RS & MK & AL & BG & RO & MD & UA & BY & LT \\
\hline \multicolumn{18}{|l|}{ NUTS-1 } \\
\hline NUTS-2 & & 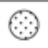 & 9 & & & & & & 0 & & & 9 & & & 3 & (2) & \\
\hline NUTS-3 & 3 & & & 3 & & & & & & & & & (3) & & & & \\
\hline NUTS-4 & & 9 & 2 & 3 & 0 & 0 & 0 & 0 & 0 & 0 & 3 & 0 & & (2) & 3 & - & 3 \\
\hline NUTS-5 & 3 & (P) & 2 & (2) & & & & & & & (3) & & 3 & 2 & 3 & (2) & 3 \\
\hline
\end{tabular}

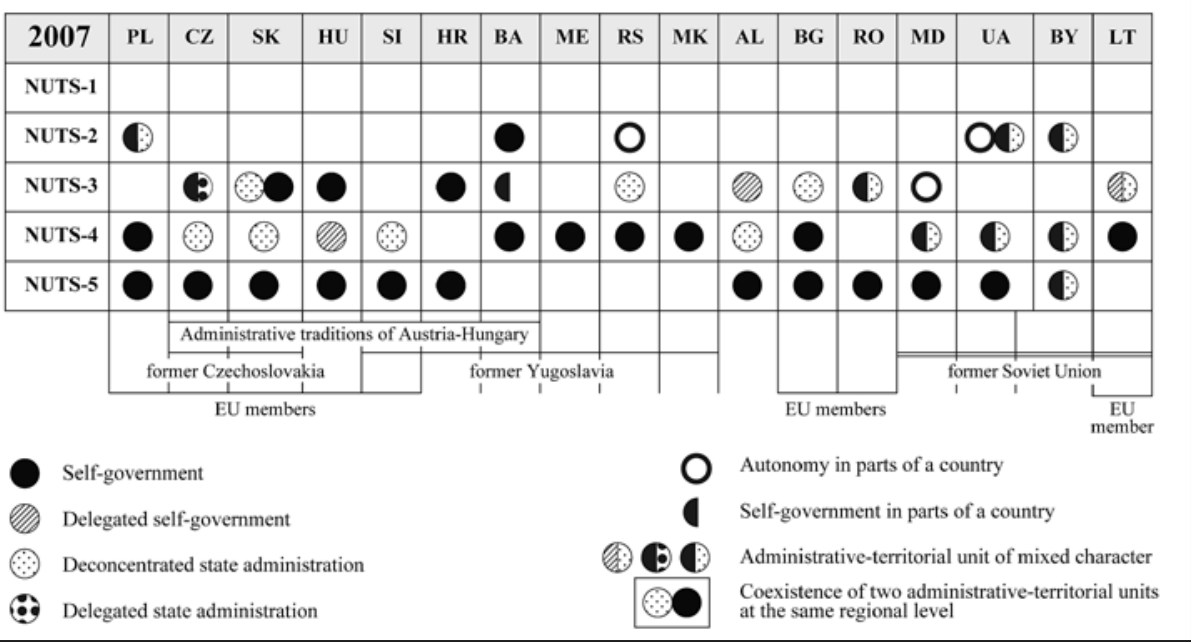

Fig. 1 Synopsis of all subnational administrative systems in East-Central and Southeast Europe as of 1.1.1989 (upper part of the scheme) compared to 1.1.2007 (lower part of the scheme)

Sl. 1. Pregled svih subnacionalnih administrativnih sustava u istočnoj i jugoistočnoj Europi na dan 1.1. 1989. (gornji dio prikaza) i 1.1. 2007. (donji dio prikaza)

centralism along with other political and social models (e.g. the close connection between Church and State).

The young nation states, including those in East-Central Europe with clear subsidiary traditions, which formed after the disintegration of the multinational empires (the Ottoman Empire, the Habsburg Empire, the Russian Tsardom) during the $19^{\text {th }}$ and $20^{\text {th }}$ centuries, were additionally impressed and influenced by the French model of a unitarian and centralist state. ${ }^{3}$

Eventually, the principle of centralism was deepened across all of East-Central, East and Southeast Europe by half a century of Communism, which was a centralist ideology par excellence, even though some Communist countries (Yugoslavia, Czechoslovakia, the Soviet Union) had federative structures (cf. to Jordan, Slawinski 1989; Roggemann 1980). But even here, the all-powerful Communist parties (the "Communist League" in Yugoslavia) controlled every level of the state and of society right down to the smallest political and economic unit.

In addition to these older factors, which still reverberate strongly today, the current situation provides good reasons, which support centralism. 
In part, large national/ethnic/cultural minorities are often perceived as a threat to the unity of the nation state. It is feared that allowing the regions where they live a greater degree of self-government is tantamount to increasing this threat. Equally, regions with a strong cultural identity are sometimes viewed as a danger for the state unity. For this reason, they should not receive additional support through self-government. Both of these factors are closely related to the new sovereignty, only recently (with great effort) obtained and often perceived as vulnerable. Centralist attitudes are often justified by pointing to the political apathy of the population, which is widespread in post-Communist countries, particularly among members of the older generation and in rural areas. This supports the argument that self-government at a regional and local level meets with little interest anyway, and is of use to very few. A further common argument used by defenders of centralist administration is the reference to the (genuinely existing) lack of qualified administrative staff, particularly in rural areas and at the lower administrative levels. By shifting competencies to the subnational levels, one causes the quality of public administration and services to decline.

Against this background, it is of no surprise that decentralisation in former Communist Europe proceeded only sluggishly and was often half-heartedly managed by national governments. The governments accepted it as a condition of European integration, but rarely acknowledged that it may well be in the interests of their own country. This is particularly true for the regional level in terms of the large and medium-sized administrative units of the NUTS-2 and NUTS-3 dimension according to the European Union (EU) classification system. ${ }^{4}$ In contrast, the local level, which consists of many small and therefore "harmless" units (usually called "communes", NUTS-4, NUTS-5) was allocated many competencies relatively quickly, though often without assigning adequate financial coverage. However, it should be recognised, that similar conditions prevail to a large extent in the "old" EU states such as France or Greece.

The European institutions (EU, European Council) have several reasons for supporting decentralisation and especially regionalisation ${ }^{5}$ :

- Both processes correspond to the principle of subsidiarity, which forms part of the guiding idea of the EU and the European Council.

- They cause the diffusion of democracy across all political levels.

- They contribute to the preservation of European cultural diversity, because "regions are the cultural building blocks of Europe".

- They allow the EU to distribute its (significant) funds for regional and structural support directly to the competent territorial-administrative units, rather than to the state governments, which then determine the allocation.

The primary incentive behind many of these motives is presumably the notion that, following World War II, the European integration project must overcome the nation state and the associated excesses of nationalism, which have caused Europe so much harm in the past two centuries. In order to achieve this it is necessary to break the power of the nation states and to shift some of their competencies to levels of the EU on the one hand, and to the level of regions and communes on the other hand. This has proved to be a laborious 
process, firstly because strong powers and interests continue to operate for the benefit of the nation states and because this process, secondly, has to be driven by representatives of the nation states themselves, who consequently effectively disempower themselves.

European identity and European awareness, but also regional identities and regional awareness would be very helpful here. A European awareness is still barely developed. Regional awareness and regional identities do exist, to a certain extent even in those countries that are not far advanced in the process of regionalisation. They are often only covered by a thin veil of national identity and could not even be made to disappear in areas where totalitarian Communist regimes particularly pursued this objective by introducing frequent changes to the administrative structure.

The strengthening of regional identities and regionalisation could be in a position to halt nationalism and to reduce the likelihood of large-scale conflicts. Switzerland offers of good example of this: thinking in national categories (German, French, Italian) is significantly fractured by the existence of small, but politically and financially powerful cantons. ${ }^{6}$

Political control and structural support by the EU could also ensure that the development of "regional feudalisms" and the increase of socio-economic disparities are prevented - two phenomena that are presented as arguments against regionalisation - and not without justification.

\section{THE CASES OF POLAND AND CROATIA}

Within this short article it is not possible to refer to all transformation countries in detail. (For a an extensive rendering of decentralisation processes in all transformation countries of East- Central and Southeast Europe see Jordan, 2010.) It is just space enough to highlight developments in two countries, i.e. Poland and Croatia. Poland stands for the case among transformation countries, which is the most advanced as regards decentralisation. Croatia is highlighted, since it is in the focus of this journal. A common feature of both countries is the existence of distinct historical and cultural subnational identities forming potential models for administrative regionalisation. Chapter 4 again widens the view to all transformation countries comparing their relative progress in decentralisation.

\section{Poland}

\section{Cultural and administrative traditions}

From the very beginning, Poland developed as an aristocratic state with relatively weak royal power (central authority). With its territorial dominions (voivodeships) the powerful nobility shaped distinctive regional identities. These were further reinforced by the fact that, over the course of history, the function of capital of the nation wandered from Poznań to Cracow [Kraków] and on to Warsaw [Warzsawa]. The personal union (1386), and later the real union (1569) with Lithuania brought Poland dominance over an empire, which - next to the Habsburg Empire - was the most important adversary against the Ottoman Empire in Europe. In the late Middle Ages the Hanseatic League spread not only along the coastal regions, but also reached far into the interior of the country, e.g. as 
far as Cracow. Together with other cities under German law they produced the bourgeoisie, which faced the sovereign and the nobility as a separate political force. Even before its three partitions in 1772, 1793 and 1795, the country was larger than it is today, and was located further to the east.

During the extremely formative phase of the $19^{\text {th }}$ and the beginning of the $20^{\text {th }}$ century (industrialisation, railway construction), the total division among Prussia (later Germany), Austria, (later Austria-Hungary) and Russia from the late $18^{\text {th }}$ century until World War I, produced very different economic and cultural influences in the three parts of the country, which reverberate to this day even though sections of the population were replaced after World War II.

In 1916, once again a "core Poland" emerged, which expanded significantly until 1923, moving to the east into areas that are Ukrainian and Belorussian today. The political post-war order forced Poland to shift to the west by $200-250 \mathrm{~km}$, which brought with it a massive population transfer. It was as late as 1992 that this was finally sealed by the German-Polish agreements.

Communist post-war Poland retained the three-tier administrative system of the interwar period, with certain modifications, until 1974. In the territory of post-war Poland it was composed of 17 voivodeships [województwo] $]^{7}$ on the upper regional level, powiats [powiat] on the lower regional level and communes [gmina] on the local level. Until 1950 the latter enjoyed self-government. As cities, Warsaw and Łódź were treated like the voivodeships. The newly acquired, previously German territories were immediately incorporated into the existing system of voivodeships in 1945, though the 1937 state borders were not reflected on the voivodeship borders.

The large voivodeships in the west were subdivided in 1950, resulting in the three new voivodeships Koszalin, Zielona Góra and Opole. Later, the large cities of Poznań, Cracow and Wrocław were each bestowed the status of a voivodeship as well. The system was heavily centralised and self-government did not exist on any level.

The increasing power of the Communist party leaders within the voivodeships led the party central office to reinforce the competencies of the communes in 1972 and 1973 , which in turn resulted in the polarisation of the balance of power between the voivodeships and the communes, and made the powiats appear superfluous. The administrative reform of 1975 took account of this, eliminated the level of the powiats, transferring most of their competencies to the communes and establishing 49 voivodeships (including 3 cities at the level of voivodeships), instead of the initial 17 (with 5 cities) (see also Jordan, Slawinski 1989).

\section{Developments 1989-2007 and the current territorial-administrative system}

An initial administrative reform immediately after the political turn-around in 1990 reintroduced the self-government of the communes in the form that had existed until 1950. The issue of the arrangement of the regional level triggered long discussions, mainly due to the number and size of the voivodeships, and these were not brought to a close until 1999 and resulted in the three-tier system that still exists today. 
Since 1.1.1999 the Polish territorial-administrative system has been composed of 16 voivodeships [województwo] on the upper regional level, 361 powiats [powiat] on the lower regional level, as well as 2,489 rural communes [gmina] and 65 urban communes [miasto] on the local level. The voivodeships correspond to the NUTS-2 level of the EU classification, the powiats to the NUTS-4 level, and the communes to the NUTS-5 level. All three levels are exclusively or additionally self-governing.

The following were significant motives for this administrative reform, and in particular for the re-introduction of large voivodeships and a three-tier system as was in place until 1975 (see Czyż 1999): the expectation of large-scale and efficient regional planning, the replacement of the "artificial" Communist system, the alignment (of the voivodeships) with historical regions, the promotion of democratisation through self-government and the need to comply with the requirements of the EU.

In many cases, the 16 voivodeships do indeed correspond at least roughly to historical cultural regions, whose identity was frequently shaped early on in the Middle Ages, and which are firmly rooted in the consciousness of the population. They often also bear the names of these historical units and cultural landscapes: Greater Poland [województwo wielkopolskie], Lesser Poland [województwo malopolskie], Masovia [województwo mazowieckie], Pomerania [województwo pomorskie], Silesia [województwo śląskie], Podlachia [województwo podlaskie], to name just those that are better known. In most cases there is also a good match with the central place system, the functional regions of the large regional centres (macrocentres). However, in some cases they are too small for the central place macroregions and divide them further (especially Katowice, Cracow, Poznań, Gdańsk). Indeed, the initial reformation plans had only provided for 12 voivodeships. The larger number was the result of the consideration of local requests.

The voivodeships simultaneously have institutions of self-government and of deconcentrated state administration ${ }^{8}$ at their disposal. For the first time in Poland's more recent history, the voivodeships are consequently self-governing.

A parliament [sejmik województwa] is elected for a term of four years and it, in turn, elects the council of the voivodeship [zarząd województwa] as its government, as well as the president ${ }^{9}$ [marszałek województwa]. Voivodeships with up to 2 million inhabitants have 45 delegates; for every additional 500,000 inhabitants, 5 further delegates are added.

The governor [wojewoda] is a representative of the deconcentrated state administration, and counterbalances these institutions of self-government. He is appointed by the Polish Council of Ministers and is thus a representative of central government. However, the council of the voivodeship has the nomination rights. The governor can annul decisions made by the self-government, if they are in violation of the national law. However, his decisions can be challenged before the administrative court. He is also responsible for public safety.

The revenues of the voivodeships are only self-generated to a very small extent (mainly as a share of property tax and income tax). Instead, they primarily consist of national transfer payments. These, too, are severely restricted and have to be renegotiated year after year. Voivodeships have the option to enter into contracts with the state about the execution of particular functions, which are then specifically funded by the state (e.g. road 
construction). Overall, this represents a rather weak financial basis for the execution of a considerable range of functions within self-government. Consequently, the effect of these competencies is very limited. Sometimes communes and powiats surrender functions to the voivodeships, together with the associated necessary funds.

The primary role of the 361 powiats is to support and coordinate the communes. They are exclusively self-governing. The powiat councils are elected for a term of four years and are made up of 20-60 delegates who, in turn, elect a chairman [starosta]. The competencies of the powiats are relatively restricted and consist mainly in the cooperation with the voivodeships and the communes in relation to their respective administrative territory.

In contrast, the 2,489 rural and 65 urban communes are endowed with much stronger competencies. They are also relatively independent financially. For their budget they receive shares of the income tax revenue in the commune and they are allowed to own property. The communal council is elected for a term of four years and has the duty to elect the communal board, which holds the executive functions.

Furthermore, the Polish Constitution provides for the instrument of the referendum in relation to all three subnational administrative levels. This can be used to remove elected institutions from office.

As far as the progress of the decentralisation process is concerned, it can be concluded that among all transformation countries, Poland has made the relatively greatest progress. It features self-government on all three subnational administrative levels; the NUTS-2 level is also furnished with self-governing territorial-administrative units and corresponds to a large extent with historically evolved cultural units. However, the financial resources of this administrative level in particular are highly insufficient.

In carrying out the spatial delineation of the voivodeships, the "danger" of providing ethnic minorities with a better opportunity to represent their interests by gathering them in one administrative unit was not evaded, even though this "danger" is objectively slight in view of the average Polish minority proportion of 3.3\% (2002): for the benefit of the relatively most compact minority, the Germans in the area of Opole, the cultural region of Silesia was divided into three voivodeships. Thus, the Germans account for a share of $10 \%$ of the total population in the Voivodeship of Opole [województwo opolskie] and have good opportunities to be represented in the Council of the Voivodeship.

Particularly in the 1990s, the driving forces of the decentralisation process in Poland were the trade union movement Solidarność in co-operation with the Roman Catholic Church.

\section{Croatia}

\section{Cultural and administrative traditions}

Similarly to Slovenia, Croatia was first established as an administrative unit in the current shape in 1945 . Very much in contrast to Slovenia, however, Croatian statehood can be traced back very far into history, in fact to the $9^{\text {th }}$ century (852). However, this statehood was subject to several interruptions (the last one from 1919 to 1939), referred to shifting 
territories with shifting heartlands and varied in sovereignty from fully sovereign to a kind of autonomy (see Budak et al. 1995, Regan 2003). What is Croatia today was dominated for long periods by Venice along the Adriatic façade and by Hungary in the interior of the country, and later by Austria (1797-1805, 1813/15-1867) and Austria-Hungary (1867-1918) in both regions. Long-term territorial fragmentation and divergent rulers, each bringing with them their elites and cultural traditions, as well as late unification resulted, again very similarly to Slovenia, in very distinct patterns of historical and cultural regional identities.

And this, even though the main dividing line runs between the former countries of the Hungarian Crown and the former "Austrian lands", the latter being successors of the Venetian possessions, which lasted until 1797.

The formerly Hungarian lands were composed of Slavonia [Slavonija] and Croatia Proper, both with a high level of autonomy until 1918, as well as Baranya, Međimurje and Fiume [Rijeka] (a corpus separatum of the Hungarian Crown), all of which were integrated parts of the Kingdom of Hungary until 1918. Croatia Proper is in turn composed of several smaller cultural regions like Hrvatsko zagorje, Banija, Kordun, Lika and the Croatian Coastland [Hrvatsko primorje]. With the exception of Hrvatsko zagorje and the Croatian Coastland, the cultural and socio-economic milieu of these subregions is mainly the result of the Austrian Military Frontier [Vojna krajina] against the Ottoman Empire. For several centuries this functioned as a military glacis, was directly subordinated to the Court Council of War in Vienna and in this way was excluded from Croatian-Slavonian self-government.

The former Austrian lands also enjoyed considerable self-governance. With regard to the territory of modern Croatia, they were composed of the Croatian share in the former Austrian Littoral, i.e. Istria [Istra] and the Kvarner, as well as of Dalmatia [Dalmacija].

While the former Hungarian lands, except Rijeka and the Croatian Coastland, have a rather Pannonian or Central European character, the former Austrian provinces skirting the Adriatic Sea (as well as Rijeka and the Croatian Coastland) feature the results of a pronounced Mediterranean and Venetian influence.

In recent times, apart from Serbian separatism, which lead to a de facto secession of areas with a Serbian majority coinciding to a large extent with the former Military Frontier between 1992 and 1995, Istria has displayed the strongest signs of a regional consciousness. This culminated in some endeavours towards autonomy in the early 1990s. In the population census of 1991 , for example, $45 \%$ of the Istrian population declared ethnic affiliations other than Croatian, while 16\% declared a "regional" rather than a national affiliation (see also Heilborn, 1995). Istria had indeed never been part of any Croatian state before 1945.

With the exception of the years 1939-1941, when a Croatian Banate [Hrvatska banovina] was established, neither inter-war Yugoslavia, nor Tito-Yugoslavia after World War II reflected these historical regions in their territorial-administrative structures (Regan 2003). From 1967 onwards, the communes [općina] were enlarged to the size of districts and endowed with considerable powers of self-government, functioning as the only administrative units below the republican level. Ultimately, their number had reached 102. With an average population of 40,000 , however, they were too small to function as 
regions. Mainly for purposes of regional planning, communes joined associations [zajednica općina]. The entire territory of Croatia was covered by a total of 11 of these communal associations. They were very well aligned with the central place system, though they were not territorial-administrative units ${ }^{10}$ in their own right, but merely associations of independent communes for certain purposes.

\section{Developments 1989-2007 and the current territorial-administrative system}

Croatia had declared independence from Yugoslavia together with Slovenia on 25.6.1991, but continued to be troubled by violent conflicts until August 1995 and was burdened with significant refugee, political and economic problems for longer still.

In somewhat of a hurry and presumably also to prevent discussions, in 1993 Croatia completely reorganised its territorial-administrative system based on a Law dated 29.12.1992. It now consisted of 20 counties [županija] at the regional NUTS-3 level, plus the City of Zagreb [Grad Zagreb], which was equated to a county (Klemenčić 1993, p. 46, Borovac 2002, p. 348). This was achieved mainly by agglomerating existing communes. At that time, roughly a third of the country was not yet under the control of the Croatian state, but was occupied by the "Republic of Serbian Krajina" ["Republika Srpska Krajina"], neighbouring Bosnia-Herzegovina was still in a situation of war and Croatia as such was certainly still in danger of being involved into this war (see Klemenčić 1997). This may go some way to explain why such a swift and centralistic approach was chosen.

In two counties (the Sisak-Moslavina County [Sisačko-moslavačka županija] and the Zadar-Knin County [Zadarsko-kninska županija]), subordinate self-governing districts [kotar] were established (Klemenčić 1993, p. 46). These were territories with a majority Serbian population. These districts were conceived as an offer to give Serbs in Croatia self-organisation and representation vis-à-vis county and state on the one hand, and on the other hand, because they were subordinated to counties with a Croatian majority population, they were presumably intended as a mechanism for controlling the Serbs.

After war and violent conflict had come to an end in Croatia (August 1995), the county system was modified in shape in 1996 and on 7.2.1997 (Borovac 2002, p. 348). These boundary alterations applied particularly to the territory of the former "Serbian Republic" and the areas around Zagreb. The total number of counties remained the same. Only the two districts conceived for Serbian self-government were abandoned, as the majority of Serbs had been expelled from these areas in 1995, and returned later in much smaller numbers. There have been no further changes to the system of counties.

The counties are self-governing territorial-administrative units. Their institutions are the elected county assembly [županijska skupština], the county government [županijsko poglavarstvo] with the county prefect [župan] at its head, who is elected by the assembly. In addition, some state functions are also transferred to the counties.

The counties procure their financing by levying taxes or (in the case of delegated state competencies) in the form of transfer payments from the state. Transfer payments from the state are also made available for the purpose of socio-economic disparity equalisation, should peripheral and economically weak counties not be able to finance their statutory 
functions through self-generated revenues. Self-government at the county as well as at the local level was substantially reinforced in 2001, when centralistic attitudes prevailing in the Tuđman era (the 1990s) began to make way for other stances.

Although the county system split up the larger historical and cultural regions mentioned above, and only corresponds to smaller historical and cultural identities in three cases (the Istria County [Istarska županija] corresponds to Istria in the sense of the cultural region, not as a peninsula; the Dubrovnik-Neretva County [Dubrovačko-neretvanska županija] corresponds to the territory of the former city republic Ragusa [Dubrovnik]; Međimurje County [Međimurska županija] corresponds to the Međimurje region acquired from Hungary in 1919), it has established a kind of regional identity pattern itself in the meantime. It is, in general, well aligned with the central place system at the meso-level (meso-regions). For these reasons it has so far been able to withstand wider public discussions, which evolved in a more liberal political climate after the end of the Tuđman era (2000) and circled around the replacement of the county system by "real" regions along the lines of historical and cultural units and in the dimensional range of NUTS-2. The most popular proposal brought forward encompassed five regions, i.e. Slavonia and Baranya [Slavonija i Baranja], Dalmatia [Dalmacija], Central Croatia [Središnja Hrvatska], Littoral and Lika [Primorsko-lička regija] and the City of Zagreb [Grad Zagreb] (Slobodna Dalmacija 23/8/2000, 7).

At the local level, the 102 large "Yugoslavian-type" communes [općina] were replaced by 70 towns [grad] and 419 communes [općina] in 1992. By the time of the population census in 2001, the numbers had grown to 122 towns and 423 communes. As of 1.1.2007, the local administrative level comprised 127 towns and 429 communes, with an average of $100 \mathrm{sq} . \mathrm{km}$ and 8,000 inhabitants (NUTS-5). They are further subdivided into 6,751 settlements [naselje] at NUTS-6 level. The significant reduction in size was motivated, amongst other things, by the experiences gained previously, i.e., that the former large communes had mainly favoured their centres, while other towns and larger settlements had lost economic activities and inhabitants. Another motive for the reduction in size was to bring the administration closer to the local population and local interests.

Any settlement with more than 10,000 inhabitants qualifies as a town in the legal sense. Smaller settlements can also be declared towns for specific historical and economic reasons. A town has an elected council [gradsko vijeće] and a government [gradsko poglavarstvo] headed by the president of the council or the mayor [gradonačelnik], respectively. A commune also has an elected Council [općinsko vijeće] and a government [općinsko poglavarstvo] headed by the president of the council or the mayor [općinski načelnik], respectively. In settlements, the population is usually represented by a local mayor.

In order to fulfil their functions they can levy their own taxes. National transfer payments support communes and towns that are financially weaker.

In 2007, three statistical regions were defined at the NUTS-2 level: Northwest Croatia [Sjeverozapadna Hrvatska], Central and East (Pannonian) Croatia [Središnja i istočna (Panonska) Hrvatska] and Adriatic Croatia [Jadranska Hrvatska]. They each combine several counties and replaced an earlier proposal for 4 statistical units, which, however, was rejected by the EU, because the regions did not have sufficient inhabitants. These statistical regions 
do not have the status of territorial-administrative units within the administrative system.

Despite a wealth of predictions to the contrary, the regional level of counties, which was hastily implemented under difficult external conditions and previously had no tradition in this form, has proved to be surprisingly stable in Croatia. Even though their competencies of self-government have been steadily expanded, they continue to correspond to the centralist concept, which formed the foundation for their implementation. This is because they are too small effectively to oppose central government, and they are unable to tap into the regional consciousness, which is oriented along the lines of the large cultural and historical units (see a.o. Pusich 1996). But it is precisely this regional consciousness combined with the highly varied cultural traditions that drive this state that is still young in years and has a very fragile national identity to push regionalisation forward at this level, rather than at the level of the large cultural-historical units. In this context, the small remaining group of Serbs (2001: $4.5 \%$ ) that is widely scattered, no longer plays a part.

\section{CONCLUSIONS}

A synopsis of all subnational administrative systems in East-Central and Southeast Europe as of 1.1.1989 (upper part of the scheme) compared to 1.1.2007 (lower part of the scheme) shown in Fig. 1 suggests the following conclusions as regards progress of administrative decentralisation during the transformation period:

The local administrative level (NUTS-5; in Lithuania, Bosnia-Herzegovina, Montenegro, Serbia and Macedonia NUTS-4) is endowed with self-government, with the exception of Belorussia, which is a dictatorship. This self-government had already been established in the successor states of Yugoslavia during the Communist years, and was adopted by the other transformation countries immediately before or very soon after the political turn-around. It expresses the early quest for democratisation "from the grass roots", but with the small size of the local units it only embraces political dimensions that do not pose a threat to the central government.

The regional administrative levels (NUTS-2 to NUTS-4), on the other hand, are exclusively self-governed only in exceptional cases. Where, as in Hungary, Croatia and Bosnia-Herzegovina, this is the case, the self-government is either endowed with only moderate competencies (Hungary, Croatia) or it does not correspond to the ideal type of administrative regionalisation, but is rather a form of administratively supported and therefore solidified ethnic segregation (Bosnia-Herzegovina: entities on the NUTS-2 level and cantons at the NUTS-3 level in the federation). Slovenia, Montenegro and Macedonia have no regions.

This deficit in the decentralisation process at the regional levels, in other words with regard to a "real" administrative regionalisation - can be explained by administrative traditions, but beyond that also primarily by the poorly consolidated national identity and statehood. Against this background, different central administrations are keen to interpret various signs (ethnic and other minorities, pronounced regional identities, gravitational pull of foreign centres, socio-economic spatial disparities, etc.) as good reasons for demonstrating restraint in this matter. 
New autonomies, in the sense of partial territories of a state that are endowed with special competencies of self-government, were exclusively the result of national movements during the transformation phase (Gagauzia, Crimea; the Autonomous Province of Vojvodina already existed at the time of Yugoslavia), while regionalist movements, which occurred frequently and with vehemence, (for example, Moravia, Istria, Transcarpathia) were not able to prevail.

Administrative traditions display a strong impact. Thus, for most successor states of the Austrian-Hungarian Monarchy, deconcentrated state administration at the lower regional administrative level (NUTS-4) following the pattern of the Political Districts [Politischer Bezirk] during the end phase of the Austrian-Hungarian Monarchy is quite characteristic (Czech Republic, Slovakia, Slovenia). The different approaches chosen by Croatia and Bosnia-Herzegovina can be partially (Croatia) or fully (Bosnia-Herzegovina) explained by the circumstances of war that prevailed in the 1990s. Hungary switched to a different model only recently. In Romania, the Romanian administrative system that was tailored after the French model, unfolded itself over large sections of the inner-Carpathian territories, which had belonged to Austria-Hungary until 1918.

In contrast, in most successor states of Communist Yugoslavia, the self-governing large communes were retained at the lower regional level (Bosnia-Herzegovina, Montenegro, Serbia, Macedonia). Only Slovenia and Croatia returned to small communes immediately after gaining independence, this being the structure that had existed there prior to the years of Communist Yugoslavia.

In the successor states of the Soviet Union, state administration generally also comprises all regional levels of administration. To date, only a very partial loosening of the structure has been achieved through the introduction of elements of self-government.

What is less tangible in the synopsis, because it does not provide information about the competencies of self-government, the financial resources of self-government, the relative size of self-governing territorial-administrative units, and the correlation between self-governing subnational units and cultural-spatial identities, is the lesser degree of decentralisation, particularly at the regional level, in the territories that were moulded by the Byzantine and Ottoman cultural traditions.

\section{NOTES}

* The paper is based on research published in Committee of the Regions (1999), Jordan et al. (2001) and Jordan (2010).

1 Self-government exists when the citizens of an administrative unit govern themselves through the institutions they directly elected.

2 The principle of subsidiarity is understood to be a political guideline that allows those duties, which can be carried out by a subordinate territorial-administrative unit, actually to be performed by these, by bestowing the required powers. 
3 Which had first developed from previously subsidiary structures, as it did in England, out of the emergence of Absolutism in the early Modern Age.

4 NUTS $=$ Nomenclature des unités territoriales statistiques. The EU currently has 211 NUTS-2-regions with an average area of $15,800 \mathrm{sq} . \mathrm{km}$ and an average number of inhabitants of 1.747 million. At the NUTS-3-level there are 1,093 regions with an average area of 3,050 sq. km and an average number of inhabitants of 337,000.

5 Regionalisation in the administrative sense is understood to mean the subdivision of a state into larger territorial-administrative units that are not attributable to the local level. It always applies across the entire national territory.

6 However, some examples also exist that show that regions support national thinking, in cases where their borders coincide with the settlement area of nations: Kosovo, the Basque Lands in Spain, the Serb Entity in Bosnia-Herzegovina.

7 The official designation of the term in the local official language/s is always given in the singular nominative, even where the English expression does not correspond to number.

8 Deconcentrated state administration signifies that territorial-administrative units assume state competencies on a regional or local level, doing so on behalf of the state and with accountability towards state institutions. In this case, territorial-administrative units act as outposts of central state administration.

9 In this text, references to functional titles (e.g. his vice-mayor) always represent both the female and male form. It would impede legibility if both forms (his/her) were used throughout. The use of the female form only would introduce a greater discrepancy with reality, as the majority of officials are male at this time.

${ }_{10}$ The term territorial-administrative unit describes a juridical person of the public administration with a territorially defined sphere of operation. This definition does not include planning regions, development regions or statistical regions, which - as a rule - do not have their own legal personality and are merely regional or local institutions that are combined for a particular purpose.

\section{REFERENCES}

Borovac, I. (ed.), 2002: Veliki atlas Hrvatske, Mozaik knjiga, Zagreb.

Budak, N., et al. (eds.), 1995: Kroatien, Böhlau, Wien - Köln - Weimar.

Committee of the Regions (ed.), 1999: Preparing for EU Enlargement. Devolution in the First Wave of Candidate Countries (= COR Studies, E-4/99). COR, Brussels.

Czyż, T., 1999: Die neue territoriale Struktur der Verwaltung und die regionale sozioökonomische Struktur in Polen, Europa Regional 7 (1), 33-42.

Heilborn, A., 1995: Istrien: Kroatiens Herz schlägt eigensinnig. Kroatiens größte Ferienregion und seine Regionalpartei IDS. In: Budak, N. et al. (eds.), Kroatien, Böhlau, Wien - Köln - Weimar, 391-410.

Jordan, P., 2010: Administrative Subdivision of Central and Southeast Europe 2007 (= Atlas of Eastern and Southeastern Europe, 5.4-G10). Borntraeger, Stuttgart.

Jordan, P., Slawinski, I., 1989: Administrative Subdivision of Eastern and Southeastern Europe (= Atlas of Eastern and Southeastern Europe, 5.1-G1). Borntraeger, Stuttgart.

Jordan, P. et al., 2001: The Europe of the Regions: Strategies and Perspectives in the View of the Forthcoming Enlargement of the European Union (Part II on Bulgaria, Latvia, Lithuania, Malta, Romania, Slovakia and Turkey). Study on behalf of the Committee of the Regions of the European Union (COR). COR, Brussels. 
Klemenčić, M. (ed.), 1993: A Concise Atlas of the Republic of Croatia \& of the Republic of Bosnia and Hercegovina, The Miroslav Krleža Lexicographical Institute, Zagreb.

Klemenčić, M. (ed.), 1997: Atlas Europe, The Miroslav Krleža Lexicographical Institute, Zagreb.

Paasi, A., 1995: The institutionalization of regions: a theoretical framework for understanding the emergence of regions and the constitution of regional identity, Fennia 164 (1), 105-146.

Pusich, Sc. M., 1996: The Case of Regionalism in Croatia. In: Hall, D., Danta, D. (eds.): Reconstructing the Balkans. A Geography of the New Southeast Europe. John Wiley \& Sons, Chichester et al., 53-65.

Regan, K. (ed.), 2003: Hrvatski povijesni atlas, The Miroslav Krleža Lexicographical Institute, Zagreb.

Roggemann, H., 1980: Die Verfassung der SFR Jugoslawien. Berlin-Verlag, Berlin.

Slobodna Dalmacija, Split 23/8/2000.

Received (Primljeno): 2010 - 12 - 20

Accepted (Prihvaćeno): 2011 - 03 - 01

Peter Jordan, PhD, Associate Professor Institute of Urban and Regional Research, Austrian Academy of Science, Vienna, Austria Peter.Jordan@oeaw.ac.at 
